\title{
THE EFFECT OF ANTINOCICEPTIVE FLAVONOID ON LEEA INDICA LEAVES FOR OROFACIAL PAIN OF ADULT ZEBRA FISH (DANIO RERIO)
}

\author{
Mei Putra Daya ${ }^{1}$, Arman Yurisaldi Saleh $^{2}$, Riezky Valentina Astari ${ }^{3}$ \\ ${ }^{1}$ Falculty of Medicine, UPN Veteran Jakarta, Indonesia \\ ${ }^{2,3}$ Department of Neurology, Faculty of Medicine, UPN Veteran Jakarta, Indonesia
}

\section{ABSTRACT}

Pain affects millions of people around the world and is one of the most frequent complaints in the medical office. Pain involves various behavioral and emotional aspects, and when persistent it can become debilitating, impairing occupational performance and producing negative impacts on the economy and public health costs. In general, commercial drugs are used to improve the quality of life of patients with chronic pain, which can result in adverse reactions. Therefore, the search for new capsules as an opportunity remedy for ache is a challenge. Pain occurs due to stimuli from pain receptors called nociceptors. One pain known in the medical world is orofacial pain, which defined as pain that occurs in soft and hard tissue in the head, face and neck area. This study aimed to determine the antinociceptive effect of flavonoids isolated from the Leea Indica plant, on orofacial pain in zebra fish (Danio Rerio), as a test model for behavior or locomotor activity. To study the orofacial pain of zebra fish induced with glutamate, this study was a true experiment. The parameter used was the number of times the fish crossed the line between the caudran from the glass petri dish during 0-5 minutes and 15-30 minutes. This study had resulted that Anova one-way test pvalue 0.0001 showed that there were differences in locomotors activity measured from 0-5 minutes and 15-30 minutes by giving flavonoids, that could affect zebra fish locomotors activity or an increase in zebra fish locomotors activity. Antinociceptive effects of flavonoids were similar to tramadol. The flavonoids from Leea Indica had antinociceptive effects on orofacial pain in adult zebra fish. The flavonoid dose of $2.5 \mathrm{mg} / \mathrm{ml}$ was a dose that had a significant difference in all treatment groups.

Keywords: Leea Indica; flavonoids; zebra fish

\section{ABSTRAK}

Nyeri mempengaruhi jutaan orang di seluruh dunia dan merupakan salah satu keluhan paling sering di dunia medis. Rasa nyeri melibatkan berbagai aspek perilaku dan emosional, dan bila terus-menerus dapat melemahkan kondisi mental, sehingga mengganggu kinerja pekerjaan dan menghasilkan dampak negatif pada ekonomi dan biaya kesehatan masyarakat. Secara umum, obat komersial digunakan untuk meningkatkan kualitas hidup pasien dengan nyeri kronis yang dapat mengakibatkan reaksi yang merugikan. Hal ini menjadi tantangan dalam pencarian obat baru sebagai pengobatan alternatif untuk nyeri. Salah satu nyeri yang dikenal dalam dunia medis adalah nyeri orofasial yang disebut sebagai nyeri yang terjadi pada jaringan lunak dan keras di area kepala, wajah dan leher. Penelitian ini bertujuan untuk mengetahui efek antinociceptive flavonoid yang diisolasi dari tanaman Leea Indica, terhadap nyeri orofasial pada ikan zebra (Danio Rerio), sebagai uji model perilaku atau aktivitas lokomotor. Untuk mempelajari nyeri orofasial, ikan zebra diinduksi dengan glutamat. Penelitian ini merupakan True experiment. Parameter yang digunakan yaitu berapa kali ikan melewati garis antara kaudran dari cawan petri kaca selama waktu 0-5 menit dan 15-30 menit, dengan analisis uji ANOVA One Way. Hasil. Uji ANOVA One Way p-value 0.0001 menunjukan terdapat perbedaan aktivitas lokomotor yang diukur 0-5 menit dan 15-30 menit dengan pemberian flavonoid dapat mempengaruhi aktivitas lokomotor ikan zebra atau terjadi peningkatan aktivitas lokomotor ikan zebra. Antinosiseptif efek flavonoid mirip dengan tramadol. Flavonoid dari Leea Indica memiliki efek antinosiseptif terhadap nyeri orofasial pada ikan zebra dewasa. Dosis flavonoid $2.5 \mathrm{mg} / \mathrm{ml}$ merupakan dosis yang memiliki perbedaan signifikan pada semua kelompok perlakuan.

Kata kunci: Leea Indica; flavonoid; ikan zebra

Correspondence: Mei Putra Daya, Faculty of Medicine, UPN Veteran Jakarta, Indonesia. Email: meiputradaya@gmail.com

pISSN:2355-8393 • eISSN: 2599-056x • doi: 10.20473/fmi.v57i2.17711

- Fol Med Indones. 2021;57:135-142 • Received 04 Feb 2020 • Accepted 07 May 2020

- Open access under CC-BY-NC-SA license • Available at https://e-journal.unair.ac.id/FMI/ 


\section{INTRODUCTION}

Pain impacts tens of thousands and thousands of human $\mathrm{s}$ round the arena and is one of the maximum frequent $\mathrm{p}$ roceedings with inside the clinical office (Magalhães et al 2017). Pain includes diverse behavioral and emotional aspects, and while continual it is able to emerge as debilitating as a result impairing occupational overall performance and generating terrible effects on the financial system and public fitness costs (do Nascimento et al 2018).

In general, commercial drugs are used to improve the quality of life of patients with chronic pain, which can result in adverse reactions (Saulino et al 2014). Therefore, the look for new capsules as an opportunity remedy for ache is a challenge. In this context, extracts acquired from medicinal vegetation had been said as being wealthy in antioxidant compounds, with antinociceptive and anti-inflammatory actions (Saravanan et al 2014). Such actions are due to the fact that the antioxidant compounds can eliminate the extracellular reactive oxygen species (eROS), originated during the nociceptive processes (Onoja et al 2017). As such, they constitute a potential source of molecules with better pharmacological activity (Wandji et al 2016).

One pain known in the medical world is orofacial pain, which is defined as pain that occurs in soft and hard tissues in the head, face and neck area (Klasser et al 2017). Orofacial pain can also be defined as pain and dysfunction that affects sensory and motor transmission to the system trigeminal nerve.

Classification and epidemiological studies of orofacial pain have a prevalence of up to $26 \%$ (Shetty et al 2015). The prevalence of orofacial pain in several countries is reported by where orofacial pain is known to be more than a quarter of the adult population (Smiljić et al 2016). The prevalence of orofacial pain in 3 countries, namely Hong Kong, Indonesia, or Brazil, known to reach more than $40 \%$ (Maulina et al 2014). Other studies report (Shetty et al 2015,) that orofacial pain affects $10 \%$ of the adult population and is more likely to occur in women than in men. This study states that orofacial pain is caused by various factors, but the most commonly reported causes of orofacial pain are pulpitis (43\%), pain due to periodontal abnormalities (32\%), pericoronitis $(13 \%)$, and temporomandibular joint disorders as many as $8 \%$ (Shetty et al 2015). Another study conducted from a city in Brazil with a prevalence of $55.5 \%$ and headaches more adults than the elderly (Klasser et al 2017). The high prevalence of orofacial pain known through preliminary studies above indicates the importance of management.
In addition to modern drugs used in the treatment of orofacial pain, traditional medicines containing flavonoids can also be used. One of the plants that has flavonoid content is girang or Leea Indica. Phytochemical screening conducted on prostate cancer Leea Indica as an anti-cancer, confirmed the presence of phyto constituents such as alkaloids, flavonoids, glycosides, phenols, lignin, saponins, sterols, tannins, anthraquinones, and sugars reduction (Ghagane et al 2017).

Methanol and ethanol extracts showed higher phenolic content compared to water extracts. The antioxidant capacity was shown to be the highest methanol and ethanol extracts based on tests conducted. Meanwhile it did not have a cytotoxic effect on normal mouse embryo fibroblast cells. Other studies have investigated the total antioxidant capacity, radical scavenging effects DPPH (1,1-diphenyl-2-picrylhydrazyl) and $\mathrm{FeCl} 3$ (Rahman et al 2013). A study also has proven that Leea Indica has phenol and total flavonoid content which is high from the excitement of girang leaves (Reddy et al 2012).

Mammalian models are generally used to develop more safe and effective pain treatment for patients. However, the issue is controversial from an ethical standpoint and has led to the development of alternative nonmammalian models. The zebra fish model has been used for the past few decades to study the development and pathophysiology of analgesic drug testing. Zebra fish or the Latin language Danio Rerio has a number of attributes that are similar to the investigation of the biology of nociception. Zebra fish (Danio Rerio) as a test species because their nervous system has many fundamental similarities with other vertebrates, including the zebra fish opioid system, has a genetic similarity with humans of about $73 \%$ (Gut et al 2017). The study conducted by (Curtright et al 2015) zebra fish (Danio Rerio) is currently a promising choice for research into illness, because of the genetic and physiological similarities of species for mammals, including between 70 and $80 \%$ analogy with humans, in addition to presenting lower costs and easy handling and care compared to other animal models, such as rat.

The evidence shows that the development and organization of devices and nociceptive centers of processing systems are similar between zebra fish and other vertebrates. In addition, these fishes can be produced in large quantities, have relatively low maintenance costs, develop rapidly that the embryo or larva has a complete nervous system and allows it to see and respond strongly to sensory stimuli. In the study of Magalhães et al (2017), adult zebra fish was proposed as a substitute method for mice in nociceptive tests. Therefore, the researchers of this study were interested 
in examining the antinociceptive effects of leaves of Leea Indica plants on adult zebra orofacial pain (Danio Rerio).

\section{MATERIALS AND METHODS}

The type of this study was experimental study in the form of treatment (intervention) on a variable to obtain changes or influence on other variables. The design of the study was true experimental with posttest only group design (Masturoh \& Nauri 2018). This study has received ethical approval from IPB with the animal code number 168-2019 IPB and ethics from Faculty of Medicine, UPN Veteran Jakarta with number B/2176/X/2019/KEPK.

\section{Test Material}

The leaf extract of the Leea Indica plant obtained from Villa the "Aromatic Garden Camp", Tenjolaya, Bogor, Indonesia. The extraction was carried out at Balai Penelitian Tanaman Rempah dan Obat Bogor (BALITTRO) with maceration method using methanol as a solvent. The chemicals used in the study were glutamate (Sigma-EUA; $12.5 \mu \mathrm{M}$ ), saline (Arboreto; $0.9 \%$ ), tramadol $50 \mathrm{ml}$ injection (do Nascimento et al 2018).

\section{Treatment}

The fish will be placed into a tank measuring $25 \mathrm{~cm} \mathrm{x}$ $16.5 \times 6.5 \mathrm{~cm}$. A handy camera was used to record the swimming behavior of the fish placed on the tank, and a $10 \times 5 \mathrm{~cm}$ petri dish and a 30 -gauge syringe. The zebra fish used were adult of both sexes aged 60-90 days with the same size $(3.5 \pm 0.5 \mathrm{~cm})$ and weight $(0.4 \pm 0.1 \mathrm{~g})$ obtained from farmers in Cibuntu Village, Pasawahan District Kuningan Regency, West Java. 30 fish were used for 24 hours in a $10 \mathrm{~L} 25 \mathrm{~cm}$ x $16.5 \times 6.5 \mathrm{~cm}$ glass tank, containing chlorinated tap water (ProtecPlus ${ }^{\circledR}$ ) and air pump with filter submerged at $25^{\circ} \mathrm{C}$ and $\mathrm{pH} 7.0$, under circadian rhythm which was almost normal (2:10 $\mathrm{pm}$ light/dark). The fishes were fed ad libitum 24 hours before the experiment (do Nascimento et al 2018).

\section{Glutamate Induced Orofacial Pain}

Orofacial nociception was induced with glutamate (glutamatergic receptors; $12.5 \mu \mathrm{M} ; 5.0 \mu \mathrm{L}$ im) on the lips $(\mathrm{n}=4 /$ group$), 30$ minutes after pretreatment, flavonoids were given $(1.0,2.5$ or $5.0 \mathrm{mg} / \mathrm{mL} ; 20 \mu \mathrm{L}$ lip), (negative control; $0.9 \%$ saline, $20 \mu \mathrm{L}$, lip) or tramdol (positive control, $50 \mathrm{~mL} ; 20 \mu \mathrm{L}$ lip). The assessment of motion instrument activity of zebra fish ( $n=4 /$ group), the naive group continued to be treated without medication. Furthermore, the treatment group that was given glutamate was treated with flavonoids (1.0, 2.5 or $5.0 \mathrm{mg} / \mathrm{mL} ; 20 \mu \mathrm{L}$ lip), the negative control group $(0.9 \%$ saline; $20 \mu \mathrm{L}$, lip), and positive control group. An opened field test was conducted to evaluate whether there was a change in motor coordination, either through sedation and/or through muscle relaxation. Then, this study calculated the percentage of crossing lines (LC\%) individually for $0-5$ minutes and 15-30 minutes on petri dishes.

\section{Procedure}

\section{Locomotors Activity Calculation}

The calculation of locomotors activity or zebra fish behavior was placed in a shelter or aquarium with a size (length $\mathrm{x}$ width $\mathrm{x}$ height) $25 \mathrm{~cm} \times 16.5 \times 6.5 \mathrm{~cm}$. Three vertical lines were drawn at the shelter with the same distance, so that they would divide the shelter into 4 zones (the length of each zone was $6.25 \mathrm{~cm}$ ). The locomotors activity was measured for 5 minutes by counting the number of lines that were passed by adult zebra fish. The activity was calculated by adding up the lines crossed by zebra fishes, divided by time and expressed in units of the number of lines that crossed every 5 minutes. The adult zebra fish had a length of 5 $\mathrm{cm}$ and the distance between vertical lines was 6.25 , so that the calculation of vertical lines that were traverse had enough sensitivity to detect the movement of fish.

Antinociceptive behavioral activity was to convert the orofacial aches and pains experienced by zebra fish to conduct a behavior analysis. This activity followed the guidelines of the study conducted by Magalhães et al (2017). After treatment and application of allogeneic agents in 150 glass bakers L, wait 30 minutes, and after which the fishes were given flavonoid through the lips and placed in glass petri dishes $(10 \times 15 \mathrm{~cm})$, petri dishes were divided into quadrants and nociceptive responses measured in terms of motion or line crossing (LC) activity for a certain time for each model. In this treatment, the percentage of analgesic activity (A\%) was calculated individually.

Zebra fishes were randomly selected, and transferred to a wet sponge for treatment with drug or control studies (3\% DMSO or $0.2 \mathrm{mg} / \mathrm{mL}$ tramadol), administered by lips, placed in an aquarium $25 \mathrm{~cm} \times 16.5 \times 6.5 \mathrm{~cm}$ containing $150 \mathrm{~mL}$ of water from the fish tank and allowed to recover for 30 minutes. Then, these fishes were injected on the lips for orofacial induction of nociception or intra peritoneal for acute toxicity. The study used an insulin syringe $(0.5 \mathrm{~mL}$; UltraFine-BD) with a 30-gauge needle. 


\section{Data Analysis}

Data processing in this study uses analytical methods with the One-Way ANOVA parametric test and continued by post-hoc test using Bonferroni test, because it had normal data distribution and homogeneous data variations. The statistical analysis program used was IBM SPSS.22.

\section{RESULTS}

The study was conducted using the line cross method or zebra fish line to find out the antinociceptive effect of the leaves of the Leea Indica plants in a dose of $1 \mathrm{mg} / \mathrm{ml}$ (Steenbergen \& Bardine 2014). $2.5 \mathrm{mg} / \mathrm{ml}$ and $5 \mathrm{mg} / \mathrm{ml}$ against zebra fish orofacial pain. In this study, there was an antinociceptive effect of flavonoids seen from zebra fish locomotors activity. Zebra fish locomotors activity was assessed by the line crossing method carry out by zebra fish. Flavonoid testing was carried out at Balai Peneltian Rempah dan Obat (BALLITRO) with the results of the test using the method of maceration of Leea Indica leaves with $17.53 \%$ results with the type of methanol extract testing and then using a quantitative test spectrophotometric test with $3.58 \%$ (Table 1).

Table 1. Test Results Analysis of the Girang leaves of Leea Indica plant

\begin{tabular}{lllll}
\hline No & $\begin{array}{l}\text { Example } \\
\text { Type }\end{array}$ & $\begin{array}{l}\text { Type of } \\
\text { Testing }\end{array}$ & $\begin{array}{l}\text { Test } \\
\text { result }\end{array}$ & $\begin{array}{l}\text { Testing } \\
\text { Method }\end{array}$ \\
\hline 1. & $\begin{array}{l}\text { Girang } \\
\text { Leaf / Leea } \\
\text { Indica }\end{array}$ & $\begin{array}{l}\text { Methanol } \\
\text { extract } \\
\text { yield (\%) } \\
17.53\end{array}$ & 17.53 & $\begin{array}{l}\text { Maceration } \\
\text { (qualitativ) }\end{array}$ \\
\hline \multirow{2}{*}{$\begin{array}{l}\text { Girang leaf } \\
\text { extract }\end{array}$} & $\begin{array}{l}\text { Flavonoids } \\
\text { as quersetin } \\
(\%)\end{array}$ & 3.58 & $\begin{array}{l}\text { Spectrophoto } \\
\text { metry } \\
\text { (quantitative) }\end{array}$ \\
\hline
\end{tabular}

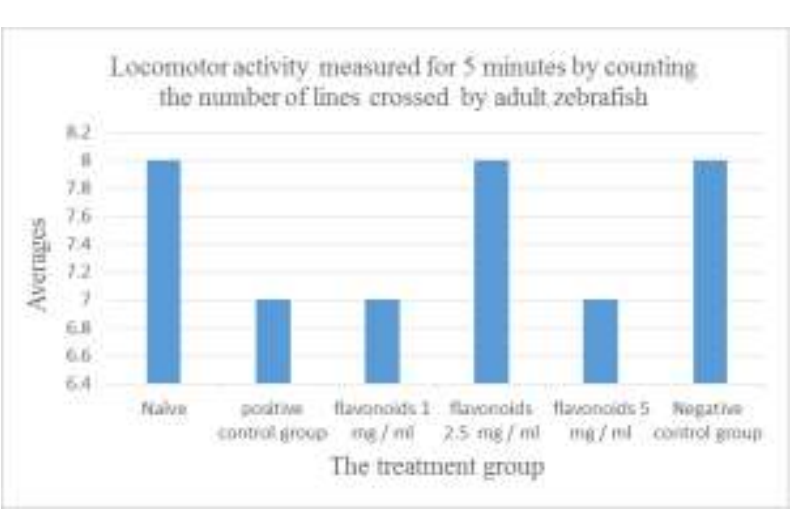

Figure 1. Locomotors activity measured for 5 minutes by counting the number of lines crossed by adult zebra fish antinociceptive effects of leaves of Leea Indica plants on orofacial pain of adult zebra fish (Danio Rerio)

The previous figure measured the locomotors activity of fish for 5 minutes before the study that purposed to assess whether the fishes used were not in a state of stress or illness. From the average, all fishes were in good condition and did not have a significant difference in line crossing in each group of fish being used.

Table 2. Average and standard deviation line crossing induction of nociceptive activity

\begin{tabular}{lcc}
\hline \multirow{2}{*}{ Groups } & \multicolumn{2}{c}{ Average \pm SD Line Crossing } \\
\cline { 2 - 3 } & $\begin{array}{c}\text { Locomotors } \\
\text { Activity }(0-5 \\
\text { minutes })\end{array}$ & $\begin{array}{c}\text { Locomotors } \\
\text { Activity } \\
(15-30 \text { minutes })\end{array}$ \\
\hline Naive & $33.00 \pm 2.160$ & $38.75 \pm 6.292$ \\
Positive Control & $32.00 \pm 4.761$ & $42.50 \pm 2.082$ \\
Group & $10.75 \pm 2.217$ & $3.75 \pm 0.957$ \\
Flavonoids 1mg/ml & $20.00 \pm 4.082$ & $13.50 \pm 2.646$ \\
Flavonoids 2.5 & $32.50 \pm 5.260$ & $34.50 \pm 2.944$ \\
Flavonoids 5 mg/ml & Negative Control \\
Group & $5.75 \pm 0.957$ & $3.00 \pm 0.816$ \\
\hline
\end{tabular}

The Table 2 indicated the average zebra crossing line of locomotors activity was 0-5 minutes, the naïve group was $33 \mathrm{~cm}$, and the naïve locomotors activity was 15-30 minutes with the average was $38.75 \mathrm{~cm}$. This happened, because there was no treatment given or no glutamate or flavonoids were given in the naive groups, so that the fishes' locomotors activity was better. In the positive control group, the locomotor activity of 0-5 minutes is smaller than in the minutes 15-30 minutes. In the flavonoid group of $1 \mathrm{mg} / \mathrm{ml}$ decreased locomotors activity at 15-30 minutes, the same thing happened in the flavonoid $2.5 \mathrm{mg} / \mathrm{ml}$ group and the negative control group, whereas in the flavonoid group $5 \mathrm{mg} / \mathrm{ml}$ obtained an increase in locomotors at measurements of 15-30 minutes. 
Table 3. Levene homogeneity test results \& normality of the antinociceptive effect of leea indica plant leaf flavonoids on oral pain in adult zebra fish

\begin{tabular}{lccc}
\hline Groups & $\begin{array}{c}\text { Shapiro-Wilk Test } \\
\text { (Sig.) }\end{array}$ & $\begin{array}{c}\text { Homogeneity Test } \\
\text { Naive }\end{array}$ & $\begin{array}{c}\text { ANOVA One-Way } \\
\text { Test }\end{array}$ \\
Positive Control Group & 0,577 & & \\
Flavonoid dose $1 \mathrm{mg} / \mathrm{ml}$ & 0,798 & 0.147 & 0,0001 \\
Flavonoid dose $2.5 \mathrm{mg} / \mathrm{ml}$ & 0,683 & & \\
Flavonoid dose $5 \mathrm{mg} / \mathrm{ml}$ & 0,368 & & \\
Negative Control Group $0.9 \%$ & 0,272 & & \\
\hline Groups & Shapiro-Wilk Test & \\
\hline Naive & (Sig.) & & \\
Positive Control Group & 0,406 & & \\
Flavonoid dose $1 \mathrm{mg} / \mathrm{ml}$ & 0,995 & & \\
Flavonoid dose $2.5 \mathrm{mg} / \mathrm{ml}$ & 0,272 & & \\
Flavonoid dose $5 \mathrm{mg} / \mathrm{ml}$ & 0,689 & & \\
Negative Control Group $0.9 \%$ & 0,734 & & \\
\hline
\end{tabular}

The Table 3 showed the normality of the data on the antinociceptive effect flavonoid leaves Leea Indica orofacial pain in adult zebra fish (Danio Rerio). The result obtained was $>0.05$. According to the hypothesis, if the value obtained was $>0.05(\mathrm{p}>0.05)$, the six data were normally distributed. Homogeneity test had obtained significant values for two Levene tests were 0.147 and 0.100 , which meant that the value was $>0.05$ (p>0.05). Therefore, if the value was $>0.05$, the variance of the data on the antinociceptive effect of Leea Indica leaf flavonoids on orofacial pain of adult zebra fish (Danio Rerio) was homogeneous; that was the variance of data had a meaning.

ANOVA One-Way test results could be seen in Table 3 which showed that the number 0.0001 meant the significant value $<0.05$. Then, there was a difference in the antinociceptive effects of leaves of Leea Indica plants on orofacial pain of adult zebra fish (Danio Rerio) on locomotors activity for 0-5 minutes and 15-30 minutes.

\section{DISCUSSION}

Orofacial pain could be induced with glutamate in adult zebra fish that are injected on the lips of adult zebra fish. Glutamate was one of the main excitatory neurotransmitters involved in the transmission of nociceptive signals through direct activation of glutamatergic receptors in nociceptive fibers, such as NMDA and AMPA, and had the ability to stimulate neural trigeminal ganglion neurons. This was because the distribution of its receptors on the face and its release after nociceptive stimulation by trigeminal terminal competitive NMDA receptor antagonists found to be effective against orofacial muscle pain in humans. Peripheral mechanisms involved autocrine and/or paracrine regulation of nociceptive neurons stimulation through injury or release of inflammation-induced glutamate into the peripheral tissues that could contribute to the development of craniofacial pain, for which to obtain orofacial pain could administer glutamate at a dose of $5 \mu \mathrm{L}$ on the lips of zebra fish using magnifying glass. The results of the study measured 0-5 minutes showed that administration of flavonoids could affect zebra fish locomotors activity or increased zebra fish locomotors activity.

The results of significant differences found in the posthoc test between the naive groups not given glutamate, and the extract did not statistically have a significant difference in changes in zebra fish locomotors activity. It showed that tramadol and flavonoid dose of $5 \mathrm{mg} / \mathrm{mg}$ had the same antinociceptive effect. A study had proven that that flavonoids or known as vitamin $\mathrm{P}$ were secondary metabolites of polyphenols that existed in most plants (Pallavi \& DS 2018). Flavonoids showed neuroprotective activity in several animal models of epilepsy and other neurological disorders in zebra fish. Apart from its antioxidant potential, fitoflavonoids work on a number of targets. The GABA ergic system, opioid receptors, and NMDA receptors (N-methyl-D-aspartate) showed a modulation effect on the sodium channel that was stressed with calcium channel and potassium channel. The flavonoids given had an effect in modulating zebra fish epilepsy. 
The negative control group was the treatment group given glutamate, but only given saline. Statistically, it did not have a significant difference or effect, but had a crossing line difference of 5.75 in the negative control group and 10.57 in the flavonoid dose group of $1 \mathrm{mg} / \mathrm{ml}$ on average. This meant that saline and a dose of 1 $\mathrm{mg} / \mathrm{ml}$ did not have an antinociceptive effect. In a group with a dose of flavonoid $1 \mathrm{mg} / \mathrm{ml}$, there was a statistically significant difference with a flavonoid dose of $2.5 \mathrm{mg} / \mathrm{ml}$ and a flavonoid dose of $5 \mathrm{mg} / \mathrm{ml}$, so that it was the same as the control group given positively tramadol. This fact showed that the administration of $2.5 \mathrm{mg} / \mathrm{ml}, 5 \mathrm{mg} / \mathrm{ml}$ and tramadol doses had a better influence on the locomotors activity of zebra fish compared to $1 \mathrm{mg} / \mathrm{ml}$. In another word, the doses of 2.5 $\mathrm{mg} / \mathrm{ml}$ and $5 \mathrm{mg} / \mathrm{ml}$ had some better antinociceptive effects than doses of $1 \mathrm{mg} / \mathrm{ml}$.

In groups with $2.5 \mathrm{mg} / \mathrm{ml}$ flavonoid doses, there were significant differences in all groups. This meant that the dose of $5 \mathrm{mg} / \mathrm{ml}$ increased zebra fish locomotors activity, but otherwise at $1 \mathrm{mg} / \mathrm{ml}$ dose and negative control decreased zebra fish locomotors activity, whereas positive control was using tramadol that had an influence in increasing the locomotors activity of zebra in an average of approaching dose of $5 \mathrm{mg} / \mathrm{ml}$. In line with a study conducted by do Nascimento et al (2018), the dose 2.5 of kaemferol as a part of flavonoids had an effect which showed antinociceptive effect in glutamate test.

The flavonoids dose of $5 \mathrm{mg} / \mathrm{ml}$ statistically had significant differences with doses of $1 \mathrm{mg} / \mathrm{ml}, 2.5$ $\mathrm{mg} / \mathrm{ml}$, and negative controls, while statistically a significant increase occurred at a dose of $5 \mathrm{mg} / \mathrm{ml}$. It showed that a dose of $5 \mathrm{mg} / \mathrm{ml}$ had an increase in locomotors activity that was better than the doses of 1 $\mathrm{mg} / \mathrm{ml}$ and $2.5 \mathrm{mg} / \mathrm{ml}$. In the naive group and the positive control group, there was no significant difference. This meant that a dose of $5 \mathrm{mg} / \mathrm{ml} \mathrm{had} \mathrm{the}$ same antinociceptive effect as the positive control group. This could be proven by the average crossing line group of $5 \mathrm{mg} / \mathrm{ml}$, which was 32.5 , and positive control group 32, and approached the locomotors activity of the naive group. Zebra fish (Danio Rerio) as a species with a nervous system that had fundamental similarities to other vertebrates, including opioid system (Correia et al 2011). In addition, tramadol was a synthetic opioid drug that was commonly used for pain treatment (Bachour et al 2020). This led us to choose tramadol as a positive control.

The mechanism of action of tramadol and Leea Indica content was highly different or did not have the same mechanism of action. Tramadol interacted with the opioid receptors $\mu, \delta$, or $\kappa$, which either increased post- synaptic $\mathrm{K}+$ efflux or reduced $\mathrm{Ca} 2$ + ingress, and thereby inhibiting the release of nociceptive neurotransmitters. To date, the administration of opioids to fish had produced several side effects with those reported mainly related to the cardiovascular and respiratory systems. Opioids were currently the most studied analgesic in fish, especially morphine, butorphanol, buprenorphine, and tramadol. Tramadol giving certainly had a nociceptive effect, but morphine had a good effect in analgesic testing in fish. Meanwhile, the metabolite compounds in the Leea Indica plant, namely flavonoids that had an antiinflammatory effect. In addition, the mechanism of flavonoids in inhibiting inflammation were carried out in two ways, namely inhibiting arachidonic acid and the secretion of lysosomal and endothelial enzymes, so that the proliferation and exudation of the inflammatory processed. The inhibited release of arachidonic acid from inflammatory cells would result in insufficient availability of arachidonic substrate for the cyclooxygenase and lipooxygenase pathways.

At 15-30 minutes, the observation statistically had a difference with $\mathrm{p}$-value $<0.0001$. In the post hoc test, a significant difference could be found in the zebra fish activity group, namely the naive group with the flavonoid group of $1 \mathrm{mg} / \mathrm{ml}$, the flavonoid group of 2.5 $\mathrm{mg} / \mathrm{ml}$, and the negative control group. The negative control group was naïve as well as the positive control group, the $2.5 \mathrm{mg} / \mathrm{ml}$ flavonoid group, and the $5 \mathrm{mg} / \mathrm{ml}$ flavonoid group. The flavonoids 1 with the naive group, the positive control group, the flavonoid group of 2.5 $\mathrm{mg} / \mathrm{ml}$, and the flavonoid group $5 \mathrm{mg} / \mathrm{ml}$. The flavonoid group of $2.5 \mathrm{mg} / \mathrm{ml}$ with naive group, positive control group, flavonoid of $1 \mathrm{mg} / \mathrm{ml}$, flavonoid group of 5 $\mathrm{mg} / \mathrm{ml}$ and negative control group. The flavonoid group of $5 \mathrm{mg} / \mathrm{ml}$ with positive control group, flavonoid group of $1 \mathrm{mg} / \mathrm{ml}, 2.5 \mathrm{mg} / \mathrm{ml}$ group and with a negative control group. The positive control group was $1 \mathrm{mg} / \mathrm{ml}$ flavonoid group, $2.5 \mathrm{mg} / \mathrm{ml}$ flavonoid group, $5 \mathrm{mg} / \mathrm{ml}$ group and negative control group.

When compared to 0-5 minutes zebra fish locomotors activity on average highly decreased, but not significant. There were 24 fishes were treated during the 0-5 minute measurement. No group of fish died; and in the measurement of 15-30 minutes to 14 days after the study, none of the fish died.

The significance of this study in the clinical aspect was that it had less labor and less costs, and allowed to reduce the high numbers of rodents and other vertebrates in the study of potential antinociceptive compounds (Steenbergen \& Bardine 2014), so that zebra fish as a new model system in research related to nocicepsis and pain. The number of samples used was 
still lacking to prove the benefits of Leea Indica and zebra fish as new models in nociceptive research. It was necessary to undertake large-scale research with this model to help us understand the mechanisms involved in nociception and hopefully led to the discovery of new analgesics that could be further validated by using higher-end vertebrate models.

\section{CONCLUSION}

The leaves of Leea Indica that contained flavonoids had antinociceptive effects on orofacial pain in adult zebra fish (Danio Rerio), which could increase the locomotors activity of zebra fish induced by glutamate. The amount of flavonoid dose of $2.5 \mathrm{mg} / \mathrm{ml}$ had a significant difference in in all treatment group, which meant that the best dose in this study was $2.5 \mathrm{mg} / \mathrm{ml}$.

\section{ACKNOWLEDGMENT}

The authors were thankful to Dr. dr. Arman Yurisaldi Saleh, MS, Sp.S for the funding of all this study, my friends Muhammad Ariq Fiqih, Salma Wangie and Hendro Wijayanto for their participation in helping this study. The authors also thanked to the Faculty of Veterinary Medicine, Bogor Agricultural University (IPB) as a place of study.

\section{REFERENCES}

Bachour RL, Golovko O, Kellner M, et al (2020). Behavioral effects of citalopram, tramadol, and binary mixture in zebra fish (Danio Rerio) larvae. Chemosphere 238, 0-7.

Correia AD, Cunha SR, Scholze M, et al (2011). A novel behavioral fish model of nociception for testing analgesics. Pharmaceuticals (Basel) 4, 665-680.

Curtright A, Rosser M, Goh S, et al (2015). Modeling nociception in zebra fish: A way forward for unbiased analgesic discovery. PLoS ONE 10, 1-18.

do Nascimento JET, de Morais SM, de Lisboa DS, et al (2018). The orofacial antinociceptive effect of Kaempferol-3-O-rutinoside, isolated from the plant Ouratea fieldingiana, on adult zebra fish (Danio Rerio). Biomedicine and Pharmacotherapy 107, 10301036.

Ghagane SC, Puranik SI, Kumbar VM, et al (2017). In vitro antioxidant and anticancer activity of Leea Indica leaf extracts on human prostate cancer cell lines. Integrative Medicine Research 6, 79-87.

Gut P, Reischauer S, Stainier DYR, et al (2017) Little fish, big data: Zebra fish as a model for cardiovascular and metabolic disease. Physiological Reviews 97, 889-938.

Klasser GD, Goulet JP, Laat AD, Manfredini D (2017). Classification of orofacial pain. In: Farah CS, Balasubramaniam R, McCullough MJ (eds). (2019). Contemporary oral medicine, Switzerland, Springer Nature.

Magalhães FEA, de Sousa CAPB, Santos SAAR, et al (2017) Adult Zebra fish (Danio Rerio): An Alternative Behavioral Model of Formalin-Induced Nociception. Zebrafish 14, 422-429.

Masturoh I, Nauri TA (2018). Metodologi Penelitian Kesehatan, Ministry of Health of the Republic of Indonesia. Available from http://bppsdmk.kemkes.go.id/. Accessed July 19, 2019.

Maulina T, Rachmy CN, Akhter R, et al (2014). The association between self-report of orofacial pain symptoms with age, gender, interference in activities, and socioeconomic factors surveyed in Indonesian community health centers. Asian Pac J Dent 14, 2334.

Onoja SO, Ezeja MI, Omeh YN, et al (2017). Antioxidant, anti-inflammatory and antinociceptive activities of methanolic extract of Justicia secunda Vahl leaf. Alexandria Journal of Medicine 53, 207213.

Rahman MA, Imran TB, Islam S (2013). Antioxidative, antimicrobial and cytotoxic effects of the phenolics of Leea Indica leaf extract. Saudi Journal of Biological Sciences 20, 213-225.

Reddy NS, Navanesan S, Sinniah SK, et al (2012). Phenolic content, antioxidant effect and cytotoxic activity of Leea indica leaves. BMC Complementary and Alternative Medicine 12, 1-7.

Saravanan S, Arunachalam K, Parimelazhagan T (2014). Antioxidant, analgesic, anti-inflammatory and antipyretic effects of polyphenols from Passiflora subpeltata leaves - A promising species of Passiflora Antioxidant, analgesic, anti-inflammatory and antipyretic effects of polyphenols from Passiflora sub. Industrial Crops \& Products 54, 272-280.

Saulino M, Kim PS, Shaw E (2014). Practical considerations and patient selection for intrathecal drug delivery in the management of chronic pain. Journal of Pain Research 7, 627-638.

Sharma P, Kumari S, Singh D (2018). Investigating the role of two major dietary flavonoids in zebra fish model of pentylenetetrazol-induced convulsions. Journal of Developing Drugs 7, 026-033.

Shetty A, James L, Nagaraj T, et al (2015). Epidemiology of orofacial pain: A retrospective study. Journal of Advanced Clinical \& Research Insights 2, 12-15. 
Smiljić S, Savic S, Stevanovic J, et al (2016). Prevalence and characteristics of orofacial pain in university students. Journal of Oral Science 58, 7-13.

Steenbergen PJ, Bardine N (2014). Antinociceptive effects of buprenorphine in zebra fish larvae: An alternative for rodent models to study pain and nociception?. Applied Animal Behaviour Science 152, 92-99.

Wandji BA, Bomba TFD, Awouafack, et al (2016). Antinociceptive effects of the aqueous and methanol extracts of the leaves of Pittosporum mannii Hook. F. (pittosporaceae) in mice. Journal of Ethnopharmacology 187, 224-231. 